\title{
International Development of German Enterprises on the example of the Wielkopolska Region
}

\author{
Magdalena Śliwińska, Rafał Śliwiński
}

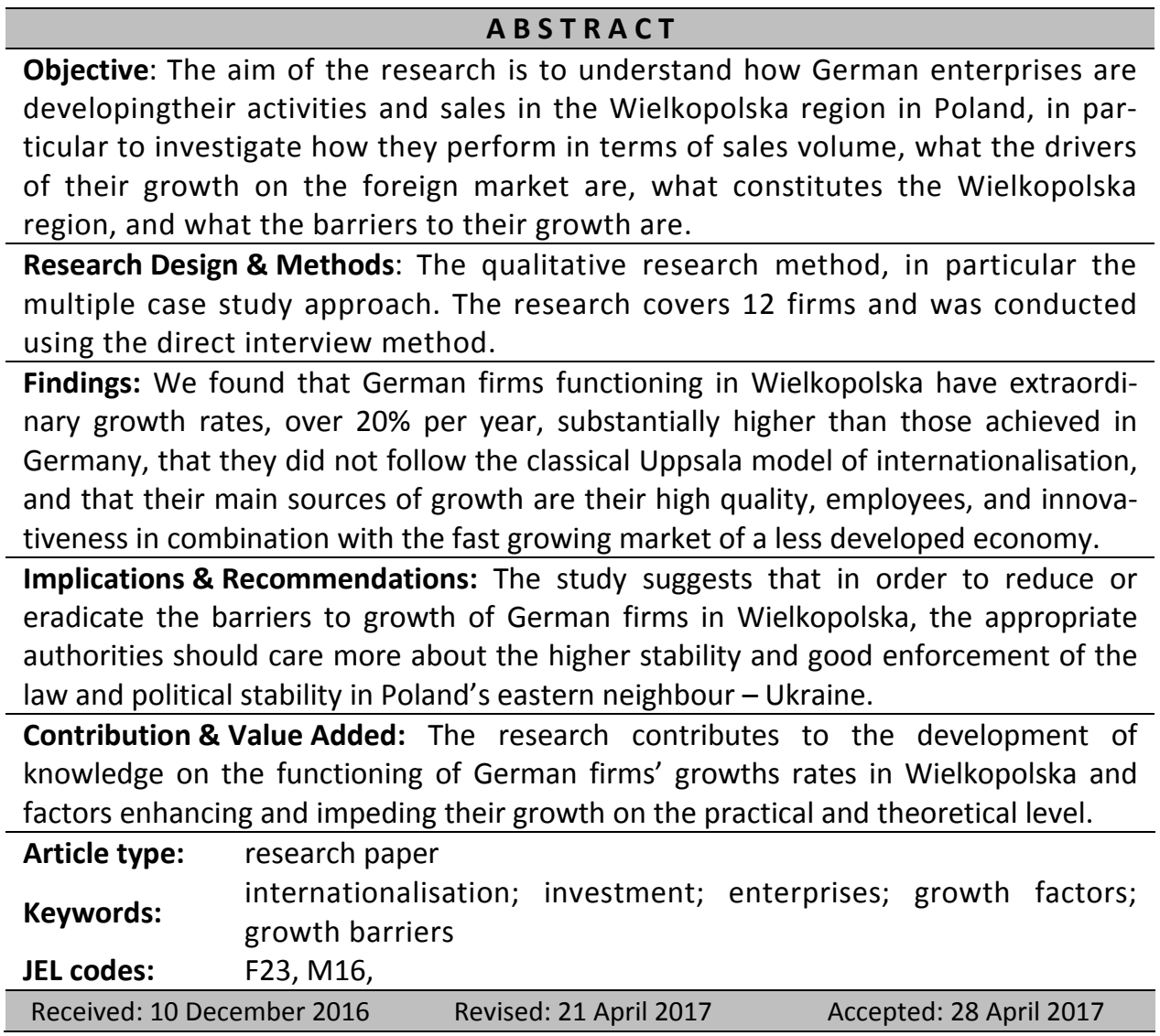

\section{Suggested citation:}

Śliwińska, M., \& Śliwiński, R. (2017). International Development of German Enterprises on the example of the Wielkopolska Region. Entrepreneurial Business and Economics Review, 5(2), 211226, DOI: http://dx.doi.org/10.15678/EBER.2017.050212 


\section{INTRODUCTION}

Wielkopolska is a region in the west of Poland and due to its geographical and historical conditions there are many economic ties between this region and the German economy. Intensification of these relations took place after 1989, when the Polish economy became more and more open to foreign trade and investors. For German firms Poland, and the Wielkopolska region as one of the closest and best developed regions in the country, was a natural direction of expansion, which is why they have become the biggest foreign employer in the region.

The functioning of foreign companies on a local market has been analysed in the literature, but despite intensive economic globalisation, it may still evoke emotions and controversies on the political and scientific levels. On the one hand, there are many studies which examine broadly understood growth factors and barriers to growth for firms functioning on foreign markets (Keen \& Etemad, 2012; Davidsson et al., 2009; Shepherd \& Wiklund, 2009). On the other hand, there are many studies concentrating on the benefits and costs of opening up areas for trade and investments from highly developed economies and the conditions necessary to achieve benefits on both sides (Dornbusch, 1992; OECD, 1999; McCulloch, Winters \& Cicera, 2001), but there are still no precise sets of factors shaping the growth of enterprises on foreign markets or their export performance. There are also no solutions found on the practical and theoretical levels, how to avoid growing inequalities between highly and lesser developed countries. For the above-mentioned reasons we decided to take a closer look at the issue of the functioning of German firms in the Wielkopolska region. Unfortunately, there is very little literature describing this issue, and it mostly refers only to cross-border exchange (Raczyk, 2014). We identified a gap in the research and literature on the description of export performance, and internationalisation strategies or growth factors of German enterprises in Poland. Therefore, the purpose of the research was to understand how German enterprises are developing their activities and sales in the Wielkopolska region in Poland, in particular to investigate how German enterprises perform in terms of sales volume, what the drivers of their growth on the foreign market are, what constitutes the Wielkopolska region, and what the barriers to their growth are.

The chosen topic seems to be highly important from the scientific and practical point of view. First, it explores the issue of growth factors and obstacles to growth of enterprises functioning on foreign markets and then it goes a step further, trying to identify the above-mentioned factors in the case when enterprises expand into relatively less developed economies, which is the case when German firms invest in the Wielkopolska region. Trying to identify new factors of growth and barriers to growth is important not only for the further development of the firm's internationalisation theory, but also for economic integration theories, as the latter explore the elements of policy and economic circumstances crucial for creating a common market between countries, giving enterprises better conditions to expand and grow. From the practical point of view, this research is important for policy makers on both sides, whose aim is to support the development of firms related to or functioning in their country or region. The findings of this research are important for attempts to estimate the implications of the functioning of German firms for the region and its economy.

The research had a qualitative character, applying the multiple case approach as a research method, and was conducted in 2015 within the confines of a bigger interna- 
tional project - CLILiG - initiated and supervised by the Goethe Institute together with University Tampere in Finland, and executed by the University of Economics in Poznań.

The paper is divided into five parts. After the introduction, the literature review on the internationalisation and export performance as the basis for the research will be analysed. In the next section the methodology of the research will be explained. Then the main findings will be described, followed, as the penultimate part, by the discussion. And the last part of the paper will present the overall conclusions.

\section{LITERATURE REVIEW}

Because of the scope and the main aim of the research, we took as the basis for considerations the internationalisation theories and literature concerning export performance. The latter is also important because the studied German companies derive a lot of the products they sell in Poland from Germany and they sell them also on the East European markets. A vital place in the research on enterprises' internationalisation is occupied by the stages theories, which imply that the internationalisation is a sequential process realised in a few phases. The dominating paradigm within these theories constitutes the Uppsala model presented by Johanson and Wiedersheim-Paul (1975). Later, Johnson and Vahlne (1977) added to the Uppsala model a dynamic perspective and proved that the next stages in the model are determined by the level of resources involved in the internationalisation process and the knowledge about foreign markets, where both are interrelated and influence each other, causing a change in the internationalisation involvement and internationalisation stage. Consequently, the model was developed further by Luostarinen (1980), Larimo (1985), Swedenborg (1982), Gandemo and Mattson (1984). Apart from the stages theory, there are other views which point to the internationalisation strategies of firms. The resource-based view of the firm (RBV) suggests that valuable, rare, inimitable and non-substitutable resources of the firm allow a company to grow (Wernerfelt, 1984; Barney, 1991; Nelson \& Winter 1982; Grant, 1991). Successful competition and reaching company's long-term aims is possible if the firm has enough resources and uses them effectively (Sharma \& Erramilli, 2004). The RBV argues that firms with valuable resources and capabilities favour high control modes of internationalisation (Ekeledo \& Sivakumar, 2004). Moreover, a specific entry strategy depends on the type of resource advantage (Malhotra, Agarwal \& Ulgado, 2003). The shortages of the RBV are reflected in difficulties in explaining the choice of some entry mode strategies (e.g. licensing vs. joint venture) and measuring some intangible assets (Malhotra et al., 2003). The organisational knowledge creation view (Nonaka \& Takeuchi, 1995) suggests that a firm learns from the experience of incidents and their location and internalises this experience in order to increase its productivity, competitiveness and growth. The external manifestation of the organisational knowledge creation view (OKCV) is that firms progressively increase efficiencies and effectively expand their product-market portfolios, including those on international markets. While the "gained experiential knowledge" in the stage models of internationalisation is tacit learning, the OKCV moves beyond such tacit states.

According to the theory, foreign-owned firms are widely assumed to have a performance advantage over their domestic counterparts. The specific comparative advantage paradigm of multinational enterprises (MNEs) (Dunning, 1988; Caves, 1974, 1996; Weche Geluebcke, 2011) points out that foreign-owned firms by definition are endowed with, 
e.g. a superior production technology or organisational superiority which is available within the entire multinational corporation at a low marginal cost due to its public good character. These advantages may, according to Dunning, be the underlying reason for internationalisation. MNEs nowadays are strongly internationalised, if not globalised. In parallel, the SME sector is catching up with MNEs internationalising more and more. Simon (2009) shows that an SME can be very successful in internationalisation, grasping even a substantial global market share. US and German SMEs are among the leaders of international competitiveness (KFW, 2014). Whilst quality, delivery times and service orientation are the key competitive advantages of German SMEs, Brazilian and Chinese SMEs compete globally based on the prices of their products or services, and in the case of the US, UK and Japan innovativeness is the main competitiveness driver. While Cooper and Kleinschmidt (1985) found a negative association between export performance (sales) and a company's size (the most frequently investigated characteristic), Kirpalani and Macintosh (1980) found no significant relationship between company size and export performance. Christensen, da Rocha and Gertner (1987) found that larger firms have more competitive advantages with respect to cost and price due to their stronger bargaining position and better human resources. The direction of the association between export performance and export experience is also unclear. Experience may help a firm select its export markets and formulate and implement its marketing strategies more effectively (Cavusgil \& Zou, 1994; Douglas \& Craig, 1989; Terpstra, 1987). Taking into consideration the above presented theories, the RBV and the OKCV seem to be most appropriate to explain the export performance of German enterprises in Wielkopolska. Whereas the stages and Dunning's theories explain the internationalisation entry strategy, they do not say much about successful growth on foreign market. The RBV points directly that the quality of resources (valuable, rare, inimitable and non-substitutable) determines success on the market (domestic and international). The OKCV adds to this perspective the dynamic of organisational development of internationalising companies which progressively increase efficiencies and effectively expand their product-market portfolios capturing market shares abroad.

\section{MATERIAL AND METHODS}

In order to achieve the aim of the study, i.e. understanding how German enterprises develop their activities and sales in the Wielkopolska region in Poland, the qualitative research method was chosen, as it provides useful in-depth findings, giving a good understanding of the behaviour of firms (Reiner et al., 2008). Due to the qualitative research method we had a chance to identify possibly new growth factors and barriers to development, whose importance and significance can be further tested in quantitative research. As a consequence, the research did not test any hypothesis, but realised the above-mentioned aim of the qualitative research (Czakon, 2013). From an array of qualitative methods the multiple case study approach was chosen, which according to Yin (2003) is the most suitable research method for theory testing, as well as for potential theory development (Eisenhardt, 1989; Merriam, 1998). This method allowed to explore and draw conclusions referring to a larger group of companies, which took place in this case (12 companies), and allowed a complex coverage of the subject and an identification of those factors which have the greatest impact on the studied phenomenon. The 
research was conducted using the direct interview method (Maxwell, 2005) and a semistructured interview (Nikodemska-Wołowik, 2008) based on a prepared questionnaire. It gave the possibility to interact directly with the respondents, to use the laddering technique deepening the answers (Reynolds \& Gutman, 1979, 1984, 1988), and to ask more in-depth questions which allowed to identify the factors which the respondent would not determine alone. Moreover, it was also possible to eliminate the situations when some questions would be unclear to the respondent, which would result in a lack of cognitive responses received. The interviews were conducted with CEOs or members of the company's Board of Directors. The adoption of this form of research had a significant impact on the quality of their responses and also allowed to get full answers to the questions that were given. Additionally, we used triangulation technique by verifying the respondent's answers with the secondary data which were derived from the companies' websites or published articles about the studied firms.

The criteria to select companies for the study was simple - a German company was supposed to have the majority of its capital in an enterprise which operated in the Wielkopolska region and it should have a presence in Wielkopolska. The assumption behind those criteria was that the chosen companies will represent different branches and different sizes in order to identify factors independent of the size of the company and the branch. There were 53 companies selected and 12 of them took part in the study (Aesculap-Chifa (ChifaBraun corporation), Anton Roehr Logistyka, Arvato (Bertelsmann corporation), BTC, Craiss Logistik, Herding Polska, Hermes, MAN, Rehau, Roedl\&Partner, Tente, Volkswagen).

In this paper we analyse the responses of the surveyed companies on the following five questions:

1. How have your sales been growing over the last 10 years on the Polish market?

2. What are the sources of growth of your firm on the Polish market?

3. What factors decide about the market success of your firm?

4. How does your firm take care of the innovativeness of products, services or processes?

5. What would now expedite the growth of your firm in practice?

The respondents could indicate one or more factors.

\section{RESULTS AND DISCUSSION}

In general, it should be noted that the studied German companies are developing on the Polish market quickly and dynamically. The BTC company has achieved a fivefold increase over the last 10 years, and Aesculap-Chifa within the 14 years of its presence on the Polish market marked a 32-fold increase, from 20 million to 640 million PLN. On the other hand, Hermes increased its turnover 8 times, and the last year's annual growth of the company stands at $30 \%$. A similar increase in turnover is recorded by Tente - with about $30 \%$ per year. This growth is not always uniform. Arvato shows that the average annual growth on the Polish market is approx. $20 \%$, but in some years it is a 55 -year-percent increase, and others 30 -or $15 \%$. Generally, an increase in the sales of the surveyed companies on the Polish market is at an average of $20-30 \%$ per annum. This also applies to companies whose detailed data we cannot disclose. Some companies also indicated that during the first few years there was a period of adjustment to the market and the lack of growth period, but in the other surveyed companies increases were noticeable from the very beginning. 
The average growth of companies in Germany has oscillated in recent years around 6\%, and it is rare there that companies have increases by 20 percent or more. This means that the growth of German companies in Poland, on average 20-30\%, are above average for German companies. The impressive results of the German firms functioning in Wielkopolska show that the growth potential of German companies in the Wielkopolska region is huge and results mainly from the combination of advanced technologies and market knowledge with the less developed Polish economy which easily absorbs new, high quality products and technologies, so in consequence with the growing market and weak local competition.

The surveyed companies paid attention to different sources of their growth, but several of them frequently overlapped. The Arvato company, BTC and Hermes emphasised the role of their employees, their enthusiasm, commitment, knowledge, ideas and skills. They identified them as the most important capital affecting the quality and efficiency of the company. On the other hand, VW, Chifa-Braun and Anton Roehr drew attention to an increase in sales and the growing market as the primary sources of growth, though in conjunction with other factors. VW, next to a continuous increase in sales, thought the focus on servicing used cars (service) to be important. Similarly, Anton Roehr felt that a combination of transport and logistical services, and the quality and reliability of services within the growing furniture market translated into the growth of their company. Aesculap-Chifa as the source of its growth recognised, alongside the growing market, the importance of product quality, the product itself and branding. The quality of services and products but also competitive price were pointed out by MAN. Essential for the growth of the company are also expanding current operations through the introduction of new products, such as: consulting in the field of EU funding (Roedl) or enlarging the market through the creation of new application areas for wheels (Tente). Likewise, innovation and continuous improvement of products (Rehau), the quality of solutions, meeting difficult challenges and investing in R\&D (Herding) and the introduction of IT systems for cost optimisation and electronic customer service (Craiss Logistik) are among the main sources of growth of German companies on the Polish market. The quality of their products and services was indicated by the studied companies most often as the source of their success. The elements affecting the quality were classified as service and customer service, which was given the highest priority. Parallel to the quality of their products, the firms' knowledge on how to operate on the market should be indicated - which allows the use of the same standards of market conduct in Poland, a country less developed than Germany,. What is more, German companies often have on the Polish market, not so much as on the stabilised German market, the ability to influence market standards and to position themselves into a good market position. With regard to the priority of quality, the research results are consistent with the results of other researchers (Simon, 2009; KFW, 2014). Prasad, Ramamurthy and Naidu (2001) argued that the possession of competencies such as product development skills, product quality, technical support/after sales service, product line breadth, cost/price competitiveness, and customer relationship skills enable a firm to enjoy superior export performance, and our research results support this statement.

The observations also pointed to a consistent and prudent operation of the studied companies in the financial sphere and to financial support from their headquarters accompanied by the support of one of the world's most powerful German state support systems, fostering the internationalisation of enterprises (Śliwiński, 2005). Re- 
source commitment and market knowledge was also found in the study by Souca et al. (2008) to be important capabilities and competencies that have an influence on a firm's export performance. The relationship between a firm's size and international experience emerged as a key determinant of export performance. This statement is not supported by our results, however, as enterprises from both the small and medium sized groups performed very well in growth on the Polish market. The same was found by Simon (2009) and Kirpalani and Macintosh (1980).

As mentioned above, as a source of their market success the companies pointed out to an appropriate ratio of value to cost of their products or services. It was very important for the studied firms that the customer understood the prices in relation to the value offered. Prasad, Ramamurthy and Naidu (2001) report a similar finding. Contrary to the above-mentioned research finding, however, Simon (2009) shows that price is definitely less important for German enterprises, with the quality of the product and an innovative product and technology supposed to be the driving force for good export sales performance. This may be, however, dependent also on the market itself, because the study about fast growing Polish companies (Śliwiński, 2011) shows that for Polish firms selling on the Polish market, similar as for the studied firms, price is only on the third place in the ranking of factors which determine sales on the Polish market. The fact that the studied companies pay attention to price may indicate the need to adjust to the Polish market, characterised by its high price elasticity in spite of the priority of quality.

Although innovativeness was perceived by the companies as very important, it seemed to be incorporated as a continuous process which is very important in the longer run but not the highest priority. The export marketing literature promotes firms' innovativeness as a critical export marketing capability (e.g., Kropp, Lindsay \& Shoham, 2006; Lages, Silva \& Styles, 2009) and as a core driver of exporters' international business success (Calantone, Cavusgil \& Zhao, 2006). The studied firms did not deny this but did not see it as being as crucial as it is portrayed in the literature (Uner et al., 2013), which can be caused by the fact that their main task is to develop sales on the local market and support the innovative process written down in the strategy of the whole firm. It may be seen differently by parent companies, which are in $100 \%$ of cases responsible for innovativeness.

The studied companies were questioned how they care about the innovativeness of their products, production processes or services. The responses indicate that they all implement a policy in terms of innovation, and in this respect a Polish subsidiary is no different than the German parent company. This does not mean, however, that all Polish subsidiaries have an R\&D department. For example, Aesculap-Chifa admits that innovations come only from the parent company, and the task of the Polish subsidiary is to send information about its acceptance and demand on the local market. In order to stimulate creativity, Chifa-Braun awards the Innovation Prize, and rewards creative ideas every year. On the other hand, Herding Holding, which allocates very large funds for research and development, delivers semi-finished and finished components to its Polish subsidiary, and the subsidiary spends money on improving them and finding ways to use these products in new situations and solving advanced technological problems at the same time. The observations showed that high attention paid to the very broad understanding of the concept of innovation varied among the studied firms. Rehau stresses the importance of 
modern methods of production processes, extensive knowledge on the use and methods of the treatment of various materials, and technical support to customers. BTC invests in new products and improving the qualifications of employees, and VW cares about innovation through the introduction of new car models, improving current models, caring for the environment and changing the sales model (from ownership to leasing). Arvato stresses that innovativeness is embedded in the company's strategy, therefore, it always tries to be "one step ahead". They constantly look for new solutions, improve the existing services and add new ones. In addition to procedures for continuous improvement, development of production and the way in which services are performed, MAN draws attention to the need to reduce resource absorption and find methods to increase their efficiency. Similarly, Roedl, next to the training of employees and employer branding, drew attention to the role of introducing the principle of lean management and new IT tools. The surveyed companies also emphasised that not only investing in R\&D, but careful focus on the customer is the source of innovation (Tente). Many ideas are born because of the current contact with customers and analysis of their needs.

Our research confirms the RBV and the quality of resources of the studied firms and the specific comparative advantage paradigm of multinational enterprises (Dunning, 1988; Caves, 1974, 1996). German firms operating in Wielkopolska are endowed with, e.g. a superior production technology or organisational superiority, giving them special benefits on the less economically developed market. However, it is worth stressing that, as mentioned above, in many cases the Polish subsidiaries develop the technologies and processes and these improvements and developments have sometimes a universal character or sometimes are specific for the Polish market. It is quite a distinctive contribution of our research to see that Poland is perceived by German investors as a place for innovation creations. This could be justified by the high educational level of the Polish society and by the fact that the necessary technology or equipment is delivered by the German parent company very often overcoming the capital barrier which many Polish enterprises cannot overcome.

In general, it should be noted that the use of certain company-wide standards that are restrained on the German market and applying innovations across the company group contributes to market changes in the Wielkopolska region that result in either raising the technical level of the market offer, or are more beneficial for employees' working conditions or other solutions. Generally, in this way, German companies impede the life of local enterprises, but in doing so they also force changes which are positive for competitiveness in local businesses, which, trying to defend their position, have to make changes and improvements both in terms of quality, technology, but also in issues related to the labour market.

All the surveyed companies started operations in Poland, either from a local sales office or from the acquisition of Polish enterprises or the launch of production in Poland (Aesculap-Chifa, VW, Rehau). In consequence, it needs to be stated that it contradicts the need of sequence in the internationalisation process described by the classical Uppsala model - which deems that the enterprises gradually increase their involvement on a foreign market. In choosing the direct form of entry into the Polish market, companies emphasise the ability to focus on quality and full control over the development activities on the foreign market. So it appears that the priority of quality has very far-reaching consequences for German companies. In the case of Aesculap- 
Chifa, VW, and Rehau, the launch of their production facility is also inconsistent with sequence internationalisation of the classical Uppsala model; however, it should be noted that these companies are corporations, which in turn means that they are interested in full commitment to the local market in order to maximise the benefits of the internationalisation decisions. As a result, their activity could be justified by the dynamic Uppsala model, which has proven that the next stages are determined by the level of resources involved in the internationalisation process and the knowledge about foreign markets. In the case of Arvato, the establishment of the production company in Poland was the first decision taken about the internationalisation process of that German company. It follows from the above considerations that the decisions of the surveyed enterprises are, however, fully justified by the resource based view.

Answers to the question about the factors that, in practice, would at present accelerate growth on the Polish market shows that German companies on the Wielkopolska market feel similar restrictions to those faced by Polish companies. However, only one company - Hermes - drew attention to the internal conditions, such as new machinery. All other companies, in turn, stressed external factors, at the international, national, regional and industry level. For Herding, where the Polish branch serves also as a gateway to eastern markets, one aspect crucial to accelerating the development would be reaching a peaceful geopolitical situation in Ukraine, which would allow, among others, to collect current receivables. MAN drew attention to the deregulation of the labour market outside Poland, which would enable faster development in our country. At the moment, this is blocked because of the protection of jobs on the German market. Attention was also paid to the lack of uniform and unambiguous laws and regulations and to the need to mitigate legal and financial regulation and improve the public procurement law (Arvato). Aesculap-Chifa drew attention to the problem of law enforcement and a decrease in attention to compliance with laws when they increase in their number. This firm also stressed the problem of the industry, which is the need to regulate the principles of the functioning of the health care system. BTC in turn drew attention to the difficulties in finding qualified staff, due to high demand for specialists on the market of Wielkopolska and an inability to compete for employees against corporations such as Samsung and Volkswagen.

There were no signs observed of any discrimination against German enterprises in Wielkopolska. The enterprises felt they were treated exactly as Polish counterparts, which is the consequence of the fact that Poland is a member state of the European single market on the one hand, and of the fact that products and services from German companies are perceived very positively by the Polish cooperates and customers on the other hand. "German" is in Poland associated with good quality. Definitely this approach of the Polish market helps a lot to achieve good sales results. Unfortunately, it does not work in the opposite direction. Very often Polish enterprises signal cases of discrimination from German administration and, secondly, that the Polish goods and services do not have the best reputation in Germany - although due to strong Polish companies such as Comarch this trend is altering. 
Table 1. Key findings

\begin{tabular}{|c|c|c|}
\hline Studied issue & Key findings & Description \\
\hline \multirow[t]{2}{*}{$\begin{array}{l}\text { 1. Sales growth in } \\
\text { last } 10 \text { years }\end{array}$} & $\begin{array}{l}\text { growth of the German companies in Poland, on average } \\
20-30 \% \text {, is above average for German companies, much } \\
\text { higher than in Germany, the home country }\end{array}$ & above average growth \\
\hline & 32-fold increase, from 20 million to 640 million PLN & individual case \\
\hline \multirow{8}{*}{$\begin{array}{l}\text { 2. Sources of firms' } \\
\text { growth }\end{array}$} & $\begin{array}{l}\text { employees, their enthusiasm, commitment, knowledge, } \\
\text { ideas and skills }\end{array}$ & emplyees \\
\hline & growing market & external factors \\
\hline & reliability of services & efficient organisation \\
\hline & meeting difficult challenges & challenges \\
\hline & product quality, the product features and branding & quality \\
\hline & $\begin{array}{l}\text { competitive price, appropriate ratio of value to cost of } \\
\text { their products or services }\end{array}$ & price \\
\hline & enlarging the market through new products or services & new products \\
\hline & $\begin{array}{l}\text { innovation and continuous improvement of products, the } \\
\text { quality of the solutions, and investing in R\&D (Herding) and } \\
\text { the introduction of IT systems for cost optimisation and } \\
\text { electronic customer service, Innovative offer }\end{array}$ & innovations \\
\hline \multirow{3}{*}{$\begin{array}{l}\text { 3. Sources of firms' } \\
\text { market success }\end{array}$} & $\begin{array}{l}\text { make the customer understand the prices in relation to the } \\
\text { value offered }\end{array}$ & price/value ratio \\
\hline & innovativeness incorporated as a continuous process & innovativeness \\
\hline & innovative product \& quality & product, quality, technology \\
\hline \multirow{8}{*}{ 4. Innovativeness } & innovations come only from the parent company & no local R\&D \\
\hline & $\begin{array}{l}\text { investment in new products and improving the qualifica- } \\
\text { tions of employees }\end{array}$ & investment in employees \\
\hline & caring for the environment and changing the sales model & environment and sales model \\
\hline & trying to be always "one step ahead" & new solutions \\
\hline & $\begin{array}{l}\text { reducing the resource absorption and finding methods to } \\
\text { increase efficiency }\end{array}$ & increasing efficiency \\
\hline & $\begin{array}{l}\text { introducing the principle of lean management and new } \\
\text { IT tools }\end{array}$ & $\begin{array}{l}\text { lean management and IT } \\
\text { tools }\end{array}$ \\
\hline & careful focus on the customer is the source of innovation & focus on customer \\
\hline & $\begin{array}{l}\text { large investment in local R\&D - product \& technological } \\
\text { problems }\end{array}$ & large local R\&D \\
\hline \multirow{8}{*}{$\begin{array}{l}\text { 5. Factors that, in } \\
\text { practice, would } \\
\text { accelerate firms' } \\
\text { growth on the } \\
\text { Polish market }\end{array}$} & new machinery & internal condition \\
\hline & reaching a peaceful geopolitical situation in Ukraine & $\begin{array}{l}\text { external condition, makroe- } \\
\text { conomic }\end{array}$ \\
\hline & deregulation of the labour market in Germany & external, labour market \\
\hline & lack of uniform and unambiguous laws and regulations & external, legal system \\
\hline & improvement of the law on public procurement & external, legal system \\
\hline & $\begin{array}{l}\text { problem of law enforcement and a decrease in attention to } \\
\text { compliance with laws }\end{array}$ & external, legal system \\
\hline & $\begin{array}{l}\text { need to regulate the principles of the functioning of the } \\
\text { health care system }\end{array}$ & external, industry specific \\
\hline & difficulties in finding highly qualified staff & internal, labour market \\
\hline
\end{tabular}

Source: own study.

Due to the fact that only German companies were studied, the obtained information puts them and their impact on the economy of the region generally in a positive light. For obvious reasons, therefore, the direct study of German companies did not provide any data on the negative impact on competitors, society, or the environment in the Wielko- 
polska region. However, it should be noted that beside the positive effects of the activities of German companies on the Polish market, there are also negative ones. The most important of them is the matter of conquering a part of the market. It is obvious that the needs of Polish consumers are limited and the demand captured by foreign companies is very hard to regain, if at all. For Polish companies, this means a much greater difficulty in reaching a certain threshold of sales or sometimes the impossibility of entering the market already occupied by a strong German company. This is a win/lose game and one should bear this in mind. From the point of view of the Polish economy it is also important that the profits will be reinvested and not transferred abroad.

\section{CONCLUSIONS}

The aim of this research was understanding how German enterprises are developing their activities and sales in the Wielkopolska region in Poland, in particular to investigate how German enterprises are performing in terms of sales volumes, what the drivers of their growth on the foreign market, in the Wielkopolska region, are and what the barriers to their growth are. The qualitative research based on the multi case study approach and in-depth interviews in 12 German firms functioning in Wielkopolska allowed to obtain answers to the questions that are aforementioned and allow to draw conclusions also on the basis of the existing literature on this topic.

All the studied firms started their activities in Poland using direct modes of internationalisation, such as sales agencies, production units or from acquiring a Polish enterprise, which denies the sequence of the classical Uppsala model but which is partly justified by the dynamic Uppsala model and well justified in the resource based theory. The average sales growth rate of the studied firms estimated about $20-30 \%$ per year, is very impressive, especially in comparison with the average growth rate of German firms on the German market in the same period. This level of growth is remarkable, especially when one takes into account that this growth covers the world crisis in the years 2008-2010, which led many German enterprises to slow-down (Wagner \& Geluebcke, 2014). Among other factors but due to very good export performance of German subsidiaries global-wide, as e.g. in Poland, the German trade has actually survived almost without harm (Statistisches Budesamt, 2015).

Our research has revealed that the studied firms do not face any discrimination on the Polish market and similarly to Polish enterprises they feel the same boundaries which local counterparts have to cope with. Almost all of them indicated external factors, like instability and poor enforcement of the law, on the branch and national level, and the political instability in the context of the conflict in Ukraine, as the Polish subsidiary is often used as a base for expansion to the East. Only one firm indicated an internal factor, namely new machinery. It shows the difference between Polish and German firms because a lot of Polish firms, especially SMEs, indicate the lack of capital for development as the basic barrier to growth.

The studied firms indicated high quality, knowledge how to operate on the market, consequent and judicious behaviour, a good ratio between price and quality, concentration on well qualified employees and clients, the constant process of innovativeness, often embedded in the strategic and operational activities, and the growing market as the main sources of their growth in Poland. It seems to be an interesting conclusion that innovations are not enumerated by the studied firms as the most important factor of growth. This can be explained by the fact that our respondents were subsidiaries not parent firms, 
and as subsidiaries they are not in $100 \%$ responsible for the innovative process, but rather they support that process, whose centre of gravity is carried out within the framework of the parent company. Their main aim is mostly to develop sales on new markets. However, an important finding of the research is also that relatively less economically developed countries are not only just the receivers of technology. From our study it follows that many subsidiaries in Poland constitute either a vital source of small, incremental innovations, or run R\&D activity which serves the entire group.

The contribution of the research is also the observation that the main source of the achieved growth for the German enterprises is the combination of the aforementioned growth factors and the fast growing, unsaturated Polish market. Without the last factor a fast growing less developed market - the firms would not generate such high growth.

From the research one can draw some implications and recommendations for practice. As the German firms are the biggest foreign investors and employers in the Wielkopolska region, the Polish authorities should care for the well-being of domestic and foreign enterprises about the higher stability and good enforcement of the law. Secondly, there should be efforts made to ensure political stability in Ukraine and between the EU and Russia, as the Polish subsidiaries are often a basis for the expansion to the East. Also the abolition of the possibility of the labour market protection in the home country (Germany) could contribute to the growth of German firms in the Wielkopolska region. On the other hand, a vital conclusion for the Polish authorities on the national and regional level should be the necessity to support local, domestic enterprises so that they could start to compete on the same level of quality and innovativeness with foreign companies on the local and international markets.

Our research has some limitations. First, as a qualitative study it could neither verify any thesis, nor conclusively prove any statement; it could and did, however, identify some new phenomena and factors which can be tested in further quantitative studies, which we would see as a further research direction, especially in the area of the growth factors and innovativeness of foreign investors in less developed countries. Second, it relied only on the statements of one or two of the highest management members and publicly available information and not on in-depth and long term analysis of the functioning of the firm. Third, the scope of the research allowed the researchers to visit only 12 German firms functioning on the Wielkopolska market. It is more than enough to conduct multiple case studies, but there can be no general judgement made. They have to be based on the quantitative studies. Fourth, in order to achieve its goal, the research covered firms from different branches with different sizes. It allows however no comparison between the studied studied companies. It is advisable to do some research among German firms functioning in Poland from the same branch and with a similar size to be able to make some comparison and more in-depth observations. Fifth, the selection criteria of companies with a presence in Wielkopolska implied that only companies with a sales subsidiary or a production facility were taken into account, leaving behind $t$ pure German exporters. It would be valuable to do a separate study with a broader scope covering also indirect entry modes of German companies into the Polish market.

Taking into account the conclusions of this paper, it would be also advisable to do a study on how to raise international competitiveness of Polish enterprises on the local and foreign markets, taking into account limitations given by the fact that Poland is 
a member of the EU and has to obey the rules on no discrimination of enterprises from other member states. It is also definitely worthwhile after 12 years of Poland being in the EU to do research which would analyse how the economic integration and openness for foreign, especially German, trade and investments contribute to the development of Poland and its catching up with the more developed economies, e.g. Germany.

\section{REFERENCES}

Barney, J.B. (1991). Firm Resources and Sustained Competitive Advantage. Journal of Management, 17(1), 99-120.

Calantone, R.J., Cavusgil, S.T., \& Zhao, Y. (2002). Learning Orientation, Firm Innovation Capability and Firm Performance. Industrial Marketing Management, 31(6), 515-24.

Caves, R.E. (1974). Multinational Firms, Competition, and Productivity in Host-Country Markets. Economica, 41(162), 176-193.

Caves, R.E. (1996). Multinational Enterprise and Economic Analysis. (2nd ed.). Cambridge/New York/Melbourne: Cambridge University Press.

Cavusgil, S.T., \& Zou, S. (1994). Marketing Strategy-Performance Relationship: An investigation of the empirical link in export market ventures. Journal of Marketing, 58(1), 1-21.

Christensen, C.H., da Rocha, A., \& Gertner, R.K. (1987). An empirical investigation of the factors influencing exporting success of Brazilian firms. Journal of International Business Studies, 18(3), 61-77.

Cooper, R.G., \& Kleinschmidt, E.J. (1985). The impact of export strategy on export sales performance. Journal of International Business Studies, 16(2), 37-55.

Czakon, W. (Ed.) (2013). Podstawy metodologii badań w naukach o zarzqdzaniu. Warszawa: Wolters Kluwer.

Dornbusch, R. (1992). The Case for Trade Liberalization in Developing Countries. Journal of Economic Perspectives, 6(1), 69-85.

Douglas, S.P., \& Craig, C.S. (1989). Evolution of global marketing strategy: Scale, scope, and synergy. Columbia Journal of World Business, 3, 47-58.

Dunning, J.H. (1988). The Eclectic Paradigm of International Production: A Restatement and Some Possible Extensions. Journal of International Business Studies, 19(1), 1-31.

Eisenhardt, K.M. (1989). Building theories from case study research. Academy of Management Review, 14(4), 532-550.

Ekeledo, I., \& Sivakumar, K. (2004). International market entry mode strategies of manufacturing firms and service firms: A resource-based perspective. International Marketing Review, 21(1), 68-101.

Gandemo, B., \& Mattson, J. (1984). Internationalization of firms - pattern and strategies. Bedriftsykonomen, 6.

Grant, R.M. (1991). The Resource-Based Theory of Competitive Advantage: Implications for Strategy Formulation. California Management Review, 33(3), 114-135.

Johanson, J., \& Wiedersheim-Paul F. (1975). The Internationalization of Firms - Four Swedish Cases. Journal of Management Studies, 12, 305-322.

Johanson, J., \& Vahlne, J.-E. (1977). The Internationalization Process of the Firm - A Model of Knowledge Development and Increasing Foreign Market Commitments. Journal of International Business Studies, 8, 23-32. 
KfW (2014). Competitiveness Indicator. Retrieved on December 10, 2016 from https://www.kfw.de /KfW-Group/Service/Download-Center/Konzernthemen-(D)/Research/Indikatoren/KfW-Wettb ewerbsindikator/ KfW-Wettbewerbsindikator.html

Kirpalani, V.H., \& Macintosh, N.B. (1980). International marketing effectiveness of technology oriented small firms. Journal of International Business Studies, 10(4), 81-90.

Kropp, F., Lindsay, N.J., \& Aviv, S. (2006). Entrepreneurial, Market, and Learning Orientations and International Entrepreneurial Business Venture Performance in South African Firms. International Marketing Review, 23(5), 504-523.

Lages, L.F., Silva, G., \& Styles, C. (2009). Relationship Capabilities, Quality, and Innovation as Determinants of Export Performance. Journal of International Marketing, 17(4), 47-70.

Larimo, J. (1985). The foreign direct investment behavior of Finnish companies. 11th European International Business Association Conference, Glasgow, 15-17.12.1985.

Luostarinen, R. (1980). Internationalization of the firm. Acta Academica Series A: 30, Helsinki: Helsinki School of Economics.

Malhotra, N., Agarwal, J., \& Ulgado, F. (2003). Internationalization and Entry Modes: A MultiTheoretical Framework and Research Propositions. Journal of International Marketing, 11(4), 1-31.

Maxwell, J.A. (2005). Qualitative research design: An interactive approach' (2nd ed.). Thousand Oaks, CA: SAGE Publications.

Merriam, S.B. (1998). Qualitative Research and Case Studies Applications in Education'. San Francisco: Jossey-Bass Publications.

McCulloch, N., Winters, L.A., \& Cicera, X. (2001). Trade Liberalization and Poverty: A Handbook. London: Centre of Economic Policy Research.

Nelson, R.R., \& Winter, S.G. (1982). An Evolutionary Theory of Economic Change. Cambridge: Harvard University Press.

Nikodemska-Wołowik, A.M. (2008). Klucz do zrozumienia nabywcy: jakościowe badania marketingowe. Warszawa: Grupa Verde.

Nonaka, I., \& Takeuchi, H. (1995). The Knowledge Creating Company: How Japanese Companies Create the Dynamics of Innovation. New York: Oxford University Press.

OECD Policy Brief (1999). Open Markets Matter: The Benefits of Trade and Investment Liberalisation. Paris: OECD.

Prasad, V.K., Ramamurthy, K., \& Naidu, G.M. (2001). The influence of Internet-marketing integration on marketing competencies and export performance. Journal of International Marketing, 9, 82-110.

Raczyk, A. (2014). Internacjonalizacja działalności podmiotów gospodarczych na przykładzie pogranicza polsko-niemieckiego. Prace Naukowe Uniwersytetu Ekonomicznego we Wrocławiu, 341, 236-244.

Reynolds, T.J., \& Gutman, J. (1984). Laddering: Extending the Repertory Grid Methodology to Construct Attribute-Consequence-Value Hierarchies. In R. Pitts \& A. Woodside (Eds.), Personal Values and Consumer Psychology (pp. 155-167). Lexington, MA: Lexington Books.

Reynolds, T.J., \& Gutman, J. (1988). Laddering theory, method, analysis and interpretation. Journal of Advertising Research, 2, 11-31.

Reynolds, T.J., \& Gutman, J. (1979). An Investigation at the Levels of Cognitive Abstraction Utilized by the Consumers in Product Differentiation. In J. Eighmey (Ed.), Attitude Research Under the Sun (pp. 128-150). Chicago: American Marketing Association.

Sharma, V.M., \& Erramilli, M.K. (2004). Resource-based Explanation of Entry Mode Choice. Journal of Marketing Theory and Practice, 4, 1-18. 
Simon, H. (2009). Hidden Champions of the Twenty-First Century: The Success Strategies of Unknown World Market Leaders. London: Springer.

Śliwiński, R. (2005). Polityka wspierania internacjonalizacji małych i średnich przedsiębiorstw w Niemczech. Zeszyty Naukowe Akademii Ekonomicznej w Poznaniu, 59, 234-246.

Śliwiński, R. (2011). Kluczowe czynniki międzynarodowej konkurencyjności przedsiębiorstw. Poznań: Wydawnictwo Uniwersytetu Ekonomicznego w Poznaniu.

Statistisches Budesamt, (2015). Deutscher Außenhandel. Export und Import im Zeichen der Globalisierung. Retrieved on December 10, 2016 from https://www.destatis.de/DE/ Publikationen/Thematisch/Aussenhandel/Gesamtentwicklung/AussenhandelWelthandel551000613900 4.pdf?_blob=publicationFile

Swedenborg, B. (1982). The multinational operations of Swedish firms. Stockholm: Almqvist and Wiksell.

Terpstra, V. (1987). International Marketing. Hinsdale, IL: The Dryden Press.

Uner, M., Kocak, A., Cavusgil, E., \& Cavusgil, S.T. (2013). Do Barriers to Export Vary for Born Globals and Across Stages of Internationalization? An Empirical Inquiry in the Emerging Market of Turkey. International Business Review, 22(5), 800-813.

Wagner, J., \& Weche Geluebcke, J.P. (2014). Risk or Resilience? The Role of Trade Integration and Foreign Ownership for the Survival of German Enterprises During the Crisis 2008-2010. Jahrbücher f. Nationalökonomie u. Statistik, 234(6), 757-774.

Weche Gelübcke, J.P. (2011). The Performance of Foreign Affiliates in German Manufacturing: Evidence from a new Database. Retrieved on December 10, 2016 from http://www.freit.org/RMET/2012 /SubmittedPapers/John_P._Weche_Geluebcke53.pdf

Wernerfelt, B. (1984). A resource-based view of the firm. Strategic Management Journal, 5, 171-180.

Yin, R.K. (2013). Case study research, design and methods, (5th ed.). Newbury Park: Sage Publications. 


\section{Authors}

The contribution share of authors is equal and amounted to $50 \%$ each of them.

\section{Magdalena Śliwińska}

PhD in Economics (Poznań University of Economics). Her research interests include competition policy of the European Union, policy of economic development, Economic Integration theory and practice.

Correspondence to: Dr Magdalena Śliwińska, Poznań University of Economics, Faculty of International Business, Chair: European Integration, al. Niepodległości 10, 61-875 Poznań, Poland, e-mail: m.sliwinska@ue.poznan.pl

\section{Rafal Śliwiński}

Associate Professor of Poznań University of Economics. His research interests include international competitiveness of enterprises, internationalization strategies, strategic management, new business models.

Correspondence to: Prof. Rafał Śliwiński, PhD, Poznan University of Economic, Faculty of International Business, Chair: International Management, al. Niepodległości 10, 61-875 Poznań, Poland, e-mail: r.sliwinski@ue.poznan.pl

\section{Copyright and License}

This article is published under the terms of the Creative Commons

Attribution - NoDerivs (CC BY-ND 4.0) License

http://creativecommons.org/licenses/by-nd/4.0/

Published by the Centre for Strategic and International Entrepreneurship - Krakow, Poland 